CASSOWARY 3 (1): 1 - 10

ISSN : 2614-8900

E-ISSN : 2622-6545

CProgram Pascasarjana Universitas Papua, https://pasca.unipa.ac.id/

\title{
Trend PNBP sektor kehutanan Provinsi Papua Barat pasca implementasi kebijakan si-puhh online dan self assesment
}

\author{
Trend of PNBP of forestry sector of Papua Barat Province following the \\ implementation of si-puhh online and self-assessment policy
}

Yuli Triestini, Bambang Nugroho, Rima H.S. Siburian*

Program Studi S2 Kehutanan, Program Pascasarjana Universitas Papua Jalan Gunung Salju, Amban, Manokwari, Papua Barat, 98314, Indonesia

*Email: rhsiburian@yahoo.com

\begin{abstract}
Changes in forest management policies by applying the Self-Assesment system, and online SI-PUHH are expected to affect the realization of PNBP for West Papua Province. How the PNBP Trends after implementing the policy in West Papua Province is a problem that will be answerd through this research. The study aims to determine trends and forecasting of PNBP Forestry Sector after the implementation of online self-assessment and SI-PUHH policies in West Papua Province. The realization of PNBP of West Papua Province originating from PSDH and DR during 2010 - 2018 shows an increasing trend even in certain years of decline. Fluctuations occur as a result of the enforcement of the self-assessment and SI-PUHH Online policies which often experience changes, especially the use of certain applications that are erquired.
\end{abstract}

Keywords: The Trend, Self Assesment, SI-PUHH Online, Policy

ABSTRAK: Perubahan kebijakan pengelolaan hutan dengan pengaplikasian sistem Self-Assessment, dan SI-PUHH online diduga akan berpengaruh terhadap realisasi PNBP bagi Provinsi Papua Barat. Bagaimana Trend PNBP pasca implementasi kebijakan tersebut di Provinsi Papua Barat menjadi masalah yang akan dijawab melalui penelitian ini. Penelitian bertujuan mengetahui trend dan peramalan PNBP Sektor Kehutanan paska implementasi kebijakan self-assesment dan SIPUH online di Provinsi Papua Barat. Realisasi PNBP Provinsi Papua Barat yang bersumber dari PSDH dan DR selama periode 2010 - 2018 menunjukkan kecenderungan yang terus meningkat sekalipun pada tahun-tahun tertentu terjadi penurunan. Fluktuasi terjadi sebagai akibat pemberlakuan kebijakan self assesment dan SI-PUHH Online yang sering mengalami perubahan terutama penggunaan aplikasi tertentu yang disyaratkan.

Kata kunci: Tren, PNBP, Self Assesment, SI-PUHH Online, Kebijakan 


\section{PENDAHULUAN}

Sektor Kehutanan merupakan salah satu sektor penyumbang devisa negara melalui penarikan dana iuran pengelolaan sumberdaya hutan yang dikenal dengan Penerimaan Negara Bukan Pajak (PNBP). PNBP sektor kehutanan terdiri atas Provisi Sumber Daya Hasil Hutan (PSDH), Dana Reboisasi (DR), Iuran Izin Usaha Pengusahaan Hutan (IIUPH) dan Ganti Rugi Tegakan (GRT). PNBP sebagai salah satu sumber dana pembangunan dari pemanfaatan hutan dan penggunaan kawasan hutan yang diterima oleh pemerintah merupakan tanggung jawab bersama antara pemerintah dan pemegang izin. Karena itu pemerintah dan pemegang izin wajib melakukan penatausahaan secara tertib, efektif, efisien, transparan dan bertanggunggugat.

Kementerian Kehutanan telah menerbitkan berbagai regulasi dan kebijakan sebagai acuan baik secara administrasi maupun secara teknis operasional. Penatausahaan perizinan dan peredaran hasil hutan serta penarikan Iuran lainnya yang sah dari pemanfaatan hutan telah mengalami berbagai perubahan. Sebelum Tahun 2014, penatausahaan dilakukan secara manual dan sejak tahun 2014 terjadi pekembangan yang mencolok sesuai dengan kemajuan teknologi informasi. Perubahan sistem penatausahaan bidang kehutanan dari sistem manual (Konvensional) ke sistem elektronik (online). Perubahan ini diawali sejak hasil kajian Litbang KPK (2014) yang menyatakan bahwa perlu memperpendek rentang kendali pelayanan pemerintahan di berbagai bidang, termasuk bidang kehutanan. Maka berdasarkan UU No. 11 Tahun 2008 tentang transaksi elektronik, pemerintah mengambil kebijakan untuk melaksanakan self-assessment bagi pemegang izin usaha pemanfaatan hasil hutan kayu, izin usaha pemanfaatan kayu serta izin sah lainnya di bidang kehutanan serta aplikasi sistem pengelolaan hutan dan sistem pencatatan keuangan elektronik (online). Atas dasar kebijakan tersebut, maka Menteri Keuangan mengeluarkan peraturan Nomor 32/pmk.05/2014 tentang system pencatatan penerimaan negara secara elektronik. Sebagai tindak lanjut dari peraturan Menteri Keuangan tersebut, maka Menteri Lingkungan Hidup dan Kehutanan mengeluarkan peraturan teknis pelaksanaan Nomor 43/MENLHKSETJEN/2015 dan No. 44/MENLHKSETJEN/2015 tentang Tata Cara Pengenaan, Pemungutan, dan Penyetoran Provisi Sumber Daya Hutan, Dana Reboisasi, Penggantian Nilai Tegakan, Ganti Rugi Tegakan dan Iuran Izin Usaha Pemanfaatan Hutan sejak tanggal 1 Januari 2016 dilakukan berbasis teknologi (paperless) dan atau melalui system aplikasi online yang terintegrasi dengan sistem pengelolaan hutan produksi lestari sebagaimana diatur oleh peraturan Menteri Lingkungan Hidup dan Kehutanan Nomor 45/MENLHKSET/2015.

Perubahan sistem penatausahaan pengelolaan hutan dari manual (konvensional) ke sistem elektronik (online) yang terintegrasi dengan sistem pengelolaan hutan produksi lestari. Semua pemegang izin wajib meningkatkan kinerja dengan berbasiskan teknologi informasi yang terintegrasi dengan pengelolaan hutan lestari (PHPL) dan verifikasi legalitas kayu (VLK). Atau dengan lain perkataan wajib beralih dari official -assessment ke self-assessment.

Berbagai alasan yang menghambat menerapan system SIPUH Online dan Self Assessment adalah keterbatasan tenaga teknis profesional, keterbatasan anggaran, ketersediaan 
sarana jaringan internet dalam lokasi penebangan. Perubahan kebijakan pengelolaan hutan dengan pengaplikasian sistem self-assessment, dan sistem SIPUH online diduga akan berpengaruh terhadap penyetoran PNBP bagi Provinsi Papua Barat. Bagaimana Trend PNBP pasca pengimplementasian kebijakan self-assesment dan Penatausahaan Iuran Kehutanan secara online di Provinsi Papua Barat? Pertanyaan ini yang menjadi masalah yang akan dijawab melalui penelitian ini.

Penelitian ini bertujuan mengetahui trend dan peramalan PNBP Sektor Kehutanan paska implementasi kebijakan self-assesment dan SIPUH online di Provinsi Papua Barat.

\section{MATERI DAN METODE Waktu dan Tempat}

Penelitian dilaksanakan di Kantor Dinas Kehutanan Provinsi Papua Barat, Kantor Cabang IUPHHK dan Base Camp IUPHHK Sasaran Penelitian.
Perusahaan yang menjadi sasaran penelitian adalah perusahaan pemegang izin sah pemanfaatan dan penggunaan hutan di Provinsi Papua Barat. yang masih aktif beroperasi selama 9 tahun terakhir .

\section{Objek dan Subyek Penelitian}

Objek peneltian adalah nilai PNBP dan penatausahaan dalam operasionalisasi self-assesment dan sistem online sektor kehutanan. Sedangkan subyek penelitian adalah perusahaan pemegang izin usaha sah pemanfaatan hasil hutan di hutan alam (IUPHHK-HA) yang menjadi sumber PNBP, terutama dari iuran PSDH dan DR.

Perusahaan subyek penelitian berjumlah 13 (Tiga Belas) unit IUPHHK merupakan unit management yang aktif berproduksi selama periode Tahun 2010-2018, seperti disajikan pada Tabel 1.

Tabel 1. Inisial, jenis izin, lokasi dan status subyek penelitian

\begin{tabular}{ccrll}
\hline \hline No. & Inisial & Jenis Izin & \multicolumn{1}{c}{ Status } & \multicolumn{1}{c}{ Lokasi } \\
\hline 1. & A & IUPHHK HA & Self Approval & Teluk Wondama \\
2. & B & IUPHHK HA & PHPL-Self Assesment & Tambrauw \\
3. & C & IUPHHK HA & PHPL-Self Assesment & Kaimana \\
4. & D & IUPHHK HA & PHPL-Self Assesment & Mankwari Selatan \\
5. & E & IUPHHK HA & PHPL-Self Assesment & Kaimana \\
6. & F & IUPHHK HA & Self Approval & Kaimana \\
7. & G & IUPHHK HA & PHPL-Self Assesment & Kaimana \\
8. & H & IUPHHK HA & Self Approval & Teluk Bintuni \\
9. & I & IUPHHK HA & Self Approval & Teluk Bintuni \\
10. & J & IUPHHK HA & PHPL-Self Assesment & Teluk Bintuni \\
11. & K & IUPHHK HA & PHPL-Self Assesment & Teluk Bintuni \\
12. & L & IUPHHK HA & PHPL-Self Assesment & Sorong \\
13. & M & IUPHHK HA & Self Approval & Teluk Bintuni \\
\hline \hline
\end{tabular}


CASSOWARY 3 (1): 1 - 10

ISSN : 2614-8900

E-ISSN : 2622-6545

CProgram Pascasarjana Universitas Papua, https://pasca.unipa.ac.id/

\section{Teknik Pengumpulan Data}

Metode penelitian menggunakan metode deskriptif dengan teknik review data sekunder. Review data sekunder dilakukan untuk mengamati semua kelengkapan dokumen pencatatan data dan dokumen administrasi yang disyaratkan dan harus dipenuhi oleh pemegang izin dalam operasionalisasi self-assesment dan sistem online termasuk di dalamnya dokumendokumen legalitas penyetoran PNBP setiap perusahaan dalam rentang waktu 10 tahun yang tersimpan di Kantor Dinas Kehutanan, Kantor Cabang Perusahaan maupun di base camp perusahaan. Data yang dikumpulkan data penyetoran Iuran Wajib, sumberdaya pendukung dan kelengkapan adminitrasi self assesment dan system online. Sedangkan Wawancara dilakukan untuk klarifikasi data hasil review dan data kualitatif terkait dengan kebijakan perusahaan dan implementasi self assesment dan system online, termasuk kendala-kendala yang dihadapi oleh perusahaan dalam mengimplementasikan kebijakan tersebut.

Seluruh data setoran sektor kehutanan provinsi Papua Barat yang tercatat di Kantor Kehutanan selama 9 (Sembilan) tahun terakhir dicatat menurut sumber penyetor dan jenis iuran wajib PSDH dan DR dari izin usaha pemanfaatan hasil hutan kayu serta dokumen pendukungnya.

\section{Variabel Pengamatan dan operasi- onalnya}

Trend PNBP sektor kehutanan pada Dinas Kehutanan Provinsi Papua Barat ( $\mathrm{Rp} / \mathrm{Thn})$, sifat positif atau negatif, Positif-negatif dan faktor trend (Rp/Tahun). Selanjutnya Nilai dugaan PNBP Tahunan Sektor Kehutanan selama kurun waktu 8 tahun ke depan pada kondisi implementasi SI-PUHH online dan self-assesment seperti yang terjadi 9 tahun terakhir (faktor trend tahunan selama 9 tahun).

\section{Pengolahan dan Analisis Data}

Data hasil pengamatan data diolah secara tabulasi sesuai dengan tujuan analisis. Untuk realisasi PNBP Tahunan di hitung perdasarkan formula sebagai berikut :

$$
\mathrm{PNBP}=\underset{\mathrm{I}=1}{\mathrm{I}=\mathrm{n}} \mathrm{PSDH}+\mathrm{DR} \quad\left(\frac{\mathrm{Rp}}{\mathrm{Thn}}\right)
$$

\section{Dimana :}

$\begin{array}{ll}\text { PSDH } & =\text { Provisi Sumberdaya Hutan } \\ D R & =\text { Dana Reboisasi }\end{array}$

Untuk tujuan mengetahui kecenderungan penerimaan PNBP tahunan provinsi Papua Barat menggunakan analisis Trend dengan menggunakan Teknik Analisis Regresi Sederhana dari data deret waktu. Model Umum Regresi sederhana sebagai berikut: (Assauri, S., 1984 dan Simon, H., 2007)

$$
Y=f(t) \text { atau } Y=a+b(t)+\mathrm{e}
$$

\section{Dimana :}

$$
\begin{aligned}
Y= & \text { realisasi penerimaan PNBB tahunan } \\
& (\text { Rp/Thn) } \\
t= & \text { waktu penerimaan }(\text { Thn }) \\
a= & \text { Intersepsi } \\
b= & \text { koefisien regresi/faktor trend } \\
e= & \text { kesalahan baku }
\end{aligned}
$$

Selanjutnya berdasarkan persamaan trend tersebut dilakukan proyeksi (peramalan) menggunakan faktor trend dengan asumsi bahwa pola trend selama periode 9 tahun tetap dan tidak ada itervensi kebijakan baru yang dilakukan. Untuk analisis trend ini digunakan paket program Minitab versi 14. 


\section{HASIL DAN PEMBAHASAN}

Realisasi PNBP Provinsi Papua Barat yang bersumber dari kegiatan pemanfaatan hutan oleh IUPHHK yang terdiri atas PSDH dan DR selama periode 2010 - 2018 berkisar antara $\mathrm{Rp}$. 73.875.552.670 - Rp. 144.308.646.359 per tahun dengan rata - rata $\mathrm{Rp}$. 110.764.876.329 per tahun. Rincian realisasi tahunan PNBP Dinas Kehutanan Provinsi Papua Barat periode 2010 -2018 seperti disajikan pada Tabel 2.

Hasil analisis trend dengan menggunakan regresi linier sederhana menunjukkan bahwa realisasi PNBP Provinsi Papua Barat yang bersumber dari IUPHHK-HA meningkat dari tahun ke tahun mengikuti persamaan hubungan $\quad \mathrm{Yt}=68781476051+$
$8395568944 * \mathrm{t}$, dengan koefisien korelasi $(r)=0.92$ dan Koefisien determinasi $\left(\mathrm{R}^{2}\right)=0.84$ Nilai koefisien korelasi dan koefisien terderminasi memperlihatkan bahwa hubungan antara waktu (tahun) dengan penerimaan PNBP sektor kehutanan Provinsi Papua Barat yang bersumber dari IUPPHK-HA sangat erat yang mana 84 persen keragaman penerimaan PNBP tersebut dapat dijelaskan oleh keragaman waktu dengan faktor trend sebesar $839.568 .944 * t$. Faktor trend ini memperlihatkan besarnya kecenderungan peningkatan tahunan PNBP Provinsi Papua Barat mengikuti garis trend positif dengan kecenderungan peningkatan tahunan sebagaimana ditunjukkan oleh Kurva pada Gambar 1.

Tabel 2. Realisasi Setoran PNBP IUPHHK-HA Periode 2010-2018

\begin{tabular}{ccccc}
\hline \multirow{2}{*}{ No. } & \multirow{2}{*}{ TAHUN } & \multicolumn{3}{c}{ Iuran Kehutanan PNBP } \\
\cline { 3 - 5 } & & PSDH & DR & TOTAL \\
\hline \hline 1 & 2010 & $34,999,962,153$ & $38,875,590,467$ & $73,875,552,620$ \\
2 & 2011 & $36,207,819,560$ & $38,036,184,741$ & $74,244,004,301$ \\
3 & 2012 & $44,725,729,474$ & $56,016,430,958$ & $100,742,160,432$ \\
4 & 2013 & $49,030,863,805$ & $63,575,154,791$ & $112,606,018,596$ \\
5 & 2014 & $43,473,792,433$ & $61,711,522,176$ & $105,185,314,610$ \\
6 & 2015 & $59,147,159,735$ & $77,858,223,179$ & $137,005,382,915$ \\
7 & 2016 & $52,676,290,883$ & $72,105,399,340$ & $124,781,690,224$ \\
8 & 2017 & $50,679,075,535$ & $73,406,041,369$ & $124,085,116,904$ \\
9 & 2018 & $62,137,383,587$ & $82,171,262,772$ & $144,308,646,359$ \\
\hline \multirow{2}{*}{ JUMLAH } & $\mathbf{4 3 3 , 0 7 8 , 0 7 7 , 1 6 6}$ & $\mathbf{5 6 3 , 7 5 5 , 8 0 9 , 7 9 5}$ & $\mathbf{9 9 6 , 8 3 3 , 8 8 6 , 9 6 1}$ \\
\hline \hline
\end{tabular}


CASSOWARY 3 (1): 1 - 10

ISSN : 2614-8900

E-ISSN : 2622-6545

CProgram Pascasarjana Universitas Papua, https://pasca.unipa.ac.id/

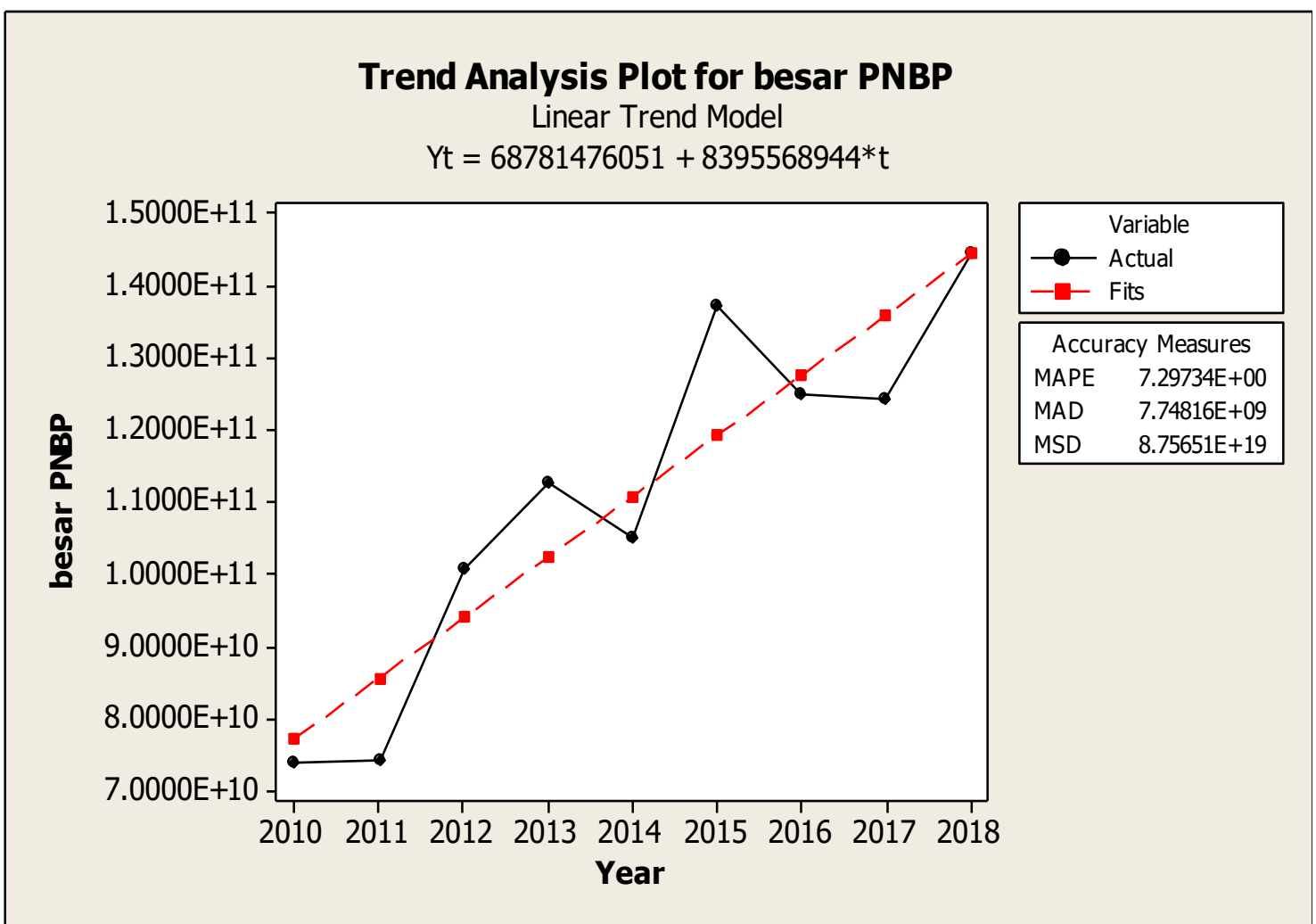

Gambar 1. Trend realisasi PNBP Provinsi Papua Barat sumber PSDH dan DR periode 2010-2018

Gambar 1. memperlihatkan bahwa secara faktual realisasi PNBP antara tahun 2010-2011 peningkatan tahunan cenderung relatif datar, tahun 2011-2012 meningkat relatif tajam, dan kembali meningkat pada tahun 2012 2013 sedangkan pada 2013-2014 terjadi penurunan relatif tajam. Selanjutnya tahun 2014-2015 kembali meningkat tajam dan tahun 2015-2016 menurun tajam serta terus menurun pada periode tahun 2016-2017, namun tahun 2017 - 2018 kembali meningkat. Fakta ini memperlihatkan bahwa cenderung terjadi ketidakstabilan dalam penyetoran PNBP oleh perusahaan yang kemungkinan disebabkan oleh adanya penundaan penyetoran pada periode tertentu pada tahun sebelumnya. Akibatnya pihak perusahaan wajib mengakumulasi penyetoran pada tahun berikutnya bersamaan dengan PNBP tahun bersangkutan. Penurunan penerimaan pada periode tahun 2013 2014 diduga sebagai akibat adanya perubahan kebijakan pada sistem penerimaan negara dari sektor kehutanan. Kementerian Keuangan mewajibkan bahwa semua penyetoran PNBP berbasis online. Kementerian Kehutanan dalam mengimplementasikan kebijakan tersebut pada setiap perusahaan sumber PNBP membutuhkan waktu dan memerlukan sosialisasi yang intensif. Pada sisi lain peraturan teknis pelaksanaannya masih belum dapat dipastikan penerbitannya. Pada Bidang Kehutanan juga terdapat beberapa kebijakan baru yang dirasakan unit management perusahaan sebagai suatu perubahan regulasi yang agak memberatkan yakni berupa perubahan Peraturan Pemerintah Nomor 12 Tahun 2014 tentang Jenis dan Tarif Atas 
Penerimaan Negara Bukan Pajak (PNBP) yang berlaku pada Kementerian Kehutanan dan adanya perubahan Peraturan Menteri Kehutanan Nomor P.68/Menhut-II/2014 tentang Penetapan Harga Patokan Hasil Hutan untuk Perhitungan PSDH, GRT dan PNT. Perubahan tarif tersebut bagi perusahaan sangat besar dan memberatkan. Akibatnya pihak management perusahaan menekan jumlah produksi sedangkan harga jual log belum merubah terutama bagi pembeli yang telah melakukan kontrak kerjasama dengan perusahaan IUPHHK-HA. Demikian juga halnya dengan penurunan yang relatif tajam pada periode 2016 -2017. Penurunan ini kemungkinan disebabkan oleh mulai diberlakukannya kebijakan sistem online sesuai dengan Peraturan Menteri Lingkungan Hidup dan Kehutanan No. 44/MenLHK-Setjen/ 2015 tentang sistem penerimaan PNBP Bidang Kehutanan secara online. Pemberlakuan regulasi ini tidak disertai dengan dukungan sumberdaya, baik sarana dan prasarana maupun SDM dan atau tenaga teknis pendukung memadai terutama pada level perusahaan. Penerapan kebijakan ini masih dalam taraf ujicoba dan aplikasi yang digunakan terus menerus mengalami perbaikan. Pihak manajemen perusahaan sebagai wajib bayar, masa ujicoba dan penyempurnaan yang terus terjadi terhadap aplikasi merupakan kendala yang menyulitkan, sedangkan pembayaran PSDH dan DR terus berjalan.

Regulasi dan kebijakan yang sering berubah tersebut menyebabkan perusahaan perlu menunggu dan mengamati (wait and see) serta menyesuaikan diri terhadap implementasi kebijakan dari pemerintah. Kondisi ini tentu berimplikasi pada kinerja perusahaan terutama pengurangan produksi dan nilai PSDH dan DR periode bersangkutan. Namun kondisi ini masih rasional dan dapat dikendalikan, karena besar kecilnya PNBP sangat bergantung pada besar kecilnya produksi pada setiap periode pelaporan produksi. Sekalipun berbagai kendala perubahan regulasi dan kebijakan sistem penyetoran PNBP sektor kehutanan, namun realisasi PNBP sektor kehutanan tahunan Provinsi Papua Barat yang bersumber dari PSDH dan DR perusahaan IUPHHKHA rata-rata menunjukkan kecenderungan positif meningkat dari tahun ke tahun selama 2010-2018. Kecenderungan fluktuasi negatif pada periode tertentu masih dapat dikendalikan oleh fluktuasi positif yang terjadi pada periode lainnya sehingga grais trend masih menunjukkan positif meningkat

Memperhatikan kecenderungan yang digambarkan seperti persamaan dan Gambar 1. maka dengan asumsi bahwa kecenderungan realisasi PNBP selama 2010-2018 tetap berlaku tanpa dilakukan intervensi kebijakan baru serta faktor trend diasumsikan tetap sama seperti pada persamaan trend di atas, maka proyeksi PNBP sektor Kehutanan Provinsi Papua Barat pada periode 2019 - 2027 terutama yang bersumber dari PSDH dan DR IUPHHK-HA seperti digambarkan pada grafik Gambar 2. 
CASSOWARY 3 (1): 1 - 10

ISSN : 2614-8900

E-ISSN : 2622-6545

(CProgram Pascasarjana Universitas Papua, https://pasca.unipa.ac.id/

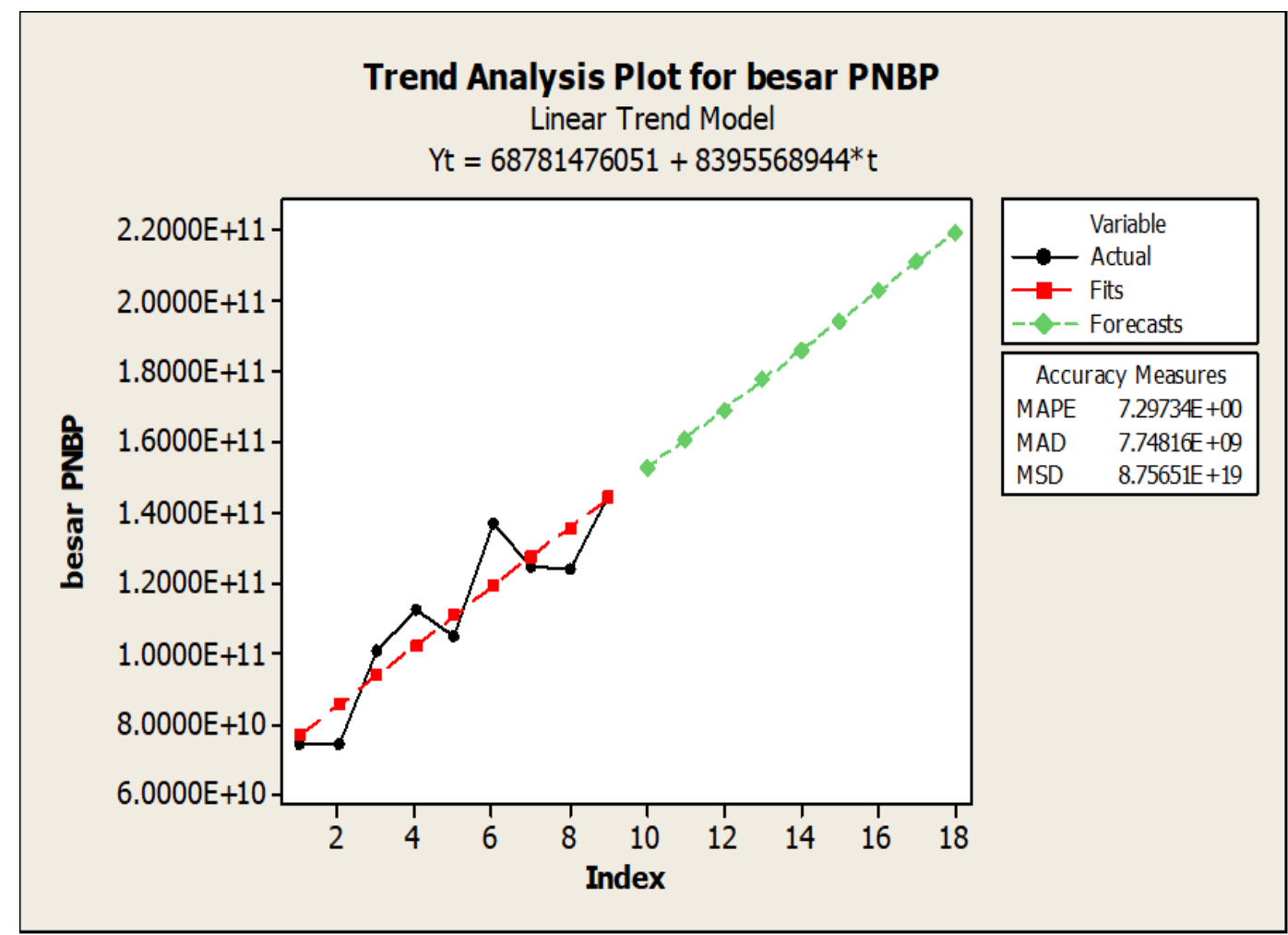

Gambar 2. Grafik hasil proyeksi PNBP Provinsi Papua Barat Sumber PSDH dan DR Tahun $2019-2027$

Nilai proyeksi PNPB tahunan sektor kehutanan yang bersumber dari PSDH dan DR IUPHHK-HA selama periode $2019-2027$ tersebut merupakan nilai rataan dari fluktuasi realisasi PNBP baik positif maupun negatif setiap tahun periode 2010-2018. Namun nilai negatif telah dapat ditutupi oleh peningkatan nilai positif yang relatif lebih besar. Dengan nilai rataan ramalan ini dapat direncanakan target realisasi tahunan PNBP Dinas Kehutanan Provinsi Papua Barat yang realistis berdasarkan kondisi obyektif lapangan. Karena itu hasil peramalan tetap ramalan yang tentunya memiliki bias. Namun dengan menggunakan data kecenderungan periode 9 tahun sebelumnya, maka ada kepastian bahwa tingkat kepastian target untuk realisasi PNBP yang bersumber dari DR dan PSDH ke 13 perusahaan IUPHHK-HA yang aktif berproduksi untuk 8 tahun mendatang secara statistik dapat dijamin. Jaminan kepastian ini akan sangat ditentukan oleh faktor lain yang mengintervensinya.

\section{KESIMPULAN}

Realisasi PNBP Provinsi Papua Barat yang bersumber dari PSDH dan DR cenderung meningkat selama periode 2010 - 2018.

Proyeksi PNBP Tahunan PNBP Sektor Kehutanan Provinsi Papua Barat sumber PSDH dan DR cenderung terus meningkat pada periode 2019 - 2027 mengikuti faktor trend $839.568 .944 * \mathrm{t}$ diasumsikan tetap serta tidak ada intervensi kebijakan baru yang akan merubah pola kecenderungan yang terjadi pada periode sebelumnya.

Faktor yang sangat mempengaruhi keberhasilan realisasi PNBP 
adalah faktor status kepemilikan sertifikasi PHPL dan SVLK, kepastian hukum kawasan IUPHHK-HA, komitment pemengan izin IUPHHKHA dan pengelolaan hutan lestari dan ketersediaan sapras khusus pendukung SI-PUHH Online.

Implementasi kebijakan self assessment dan aplikasi SI-PUHH online dinilai hanya memberikan dampak peningkatan efektivitas dan efisiensi administratif namun tidak memberikan dampak peningkatan kinerja bagi pemegang IUPHHK-HA di Provinsi Papua Barat.

\section{DAFTAR PUSTAKA}

Assauri, S. 1984. Tehnik \& Metoda Peramalan Penerapannya dalam Ekonomi \& Dunia Usaha, Edisi Satu.

Diedit.com., 2019. Pengertian Skala Likert dan Contoh Cara Hitung Kuesionernya

Direktur Jenderal Pengelolaan Hutan Produksi Peraturan Menteri Lingkungan Hidup dan Kehutanan, 2016. Peraturan Direktur Jenderal Pengelolaan Hutan Produksi Nomor P.14/PHPL/SET/4/2016 tentang Standard dan Pedoman Pelaksanaan Penilaian Kinerja Pengelolaan Hutan Produksi Lestari (PHPL) dan Verifikasi Legalitas Kayu (VLK).

Kementerian Keuangan, 2014. Peraturan Menteri Keuangan Nomor 32/pmk.05/2014 tentang system pencatatan penerimaan negara secara elektronik.

Kementerian Lingkungan Hidup dan Kehutanan, 2015. Peraturan
Menteri Lingkungan Hidup dan Kehutanan Nomor 43/MENLHK-SETJEN/2015 tentang Penata Usahaan Hasil Hutan Kayu yang berasal dari hutan alam.

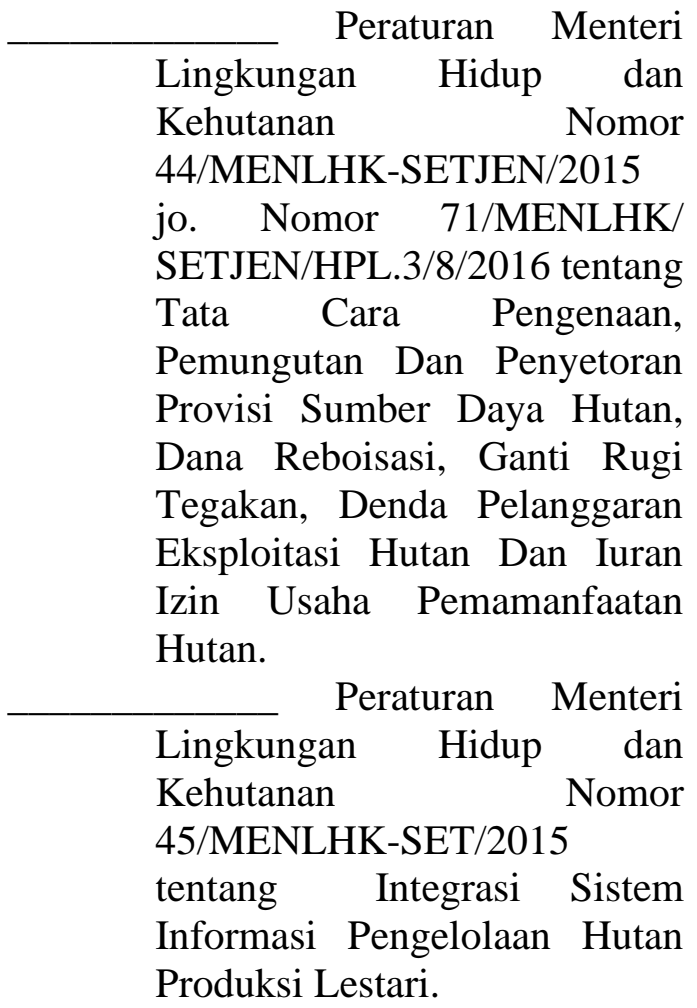

Peraturan Menteri Lingkungan Hidup dan Kehutanan Nomor : P.46/Menlhk-Setjen/2015 tentang Pedoman post audit terhadap pemegang IUPHHK dan IPK.

Pemerintah Republik Indonesia, 2008. Undang-undang No. 11 Tahun 2008 tentang Transaksi Elektronik.

Paramita Iswari, Edi Suprapto, Max J. Tokede dan Lyndon B. Pangkali, 2012. Svlk Dalam Konteks Otonomi Khusus Provinsi Papua. Stocktaking Assessment. 
Pawitno, 2003. Kontribusi Pendapatan Sub Sektor Kehutanan Terhadap Pedapatan Daerah Di Papua. Fakultas Kehutanan. Universitas Negeri Papua, Manokwari.

Simon, H. 2007. Satatistik Untuk Kehutanan. Pustaka Pelajar Yogyakarta. Cetakan I.

Supranto, J. 2009. Satatistik. Teori dan Aplikasi, Edisi Ketujuh. Penerbit Erlangga, Jakarta.
Thomopoulos, N. T., 1980. Applied Forecasting Methods. PrenticeHall, Inc., Englewood Cliffs. New Jersey.

Wanggai, R. N., 1998. Analisis Penerimaan Sektor Kehutanan Bidang Pengusahaan Hutan dan Deplesi Sumberdaya HUtan Provinsi Dati I Irian Jaya. Fakultas Pertanian. Universitas Negeri Cenderawasih, Manokwari 